\title{
A História encenada na telenovela: os brasileiros de Lado a Lado ${ }^{1}$
}

\section{Caroline Bonfim}

Pontifícia Universidade Católica do Rio de Janeiro - PUC-Rio

Departamento de Comunicação Social - Bacharelado em Publicidade

\section{RESUMO}

Este artigo busca compreender como os elementos narrativos da novela Lado a Lado constroem um imaginário coletivo de passado e qual foi o processo criativo que a estruturou. O objetivo principal é entender como se dá a interação entre o real e o ficcional na trama conduzida por fatos históricos como a Revolta da Vacina, A Revolta da Chibata, o surgimento das favelas e as mudanças durante a transição do sistema imperial para o republicado no Brasil no início do século XX. A análise principal será da elaboração das personagens e de que forma elas comunicam os temas essenciais da telenovela - racismo, machismo e corrupção - na televisão, veículo de comunicação massivo. Assim, observar qual a interpretação de nação apresentada por Lado a Lado, que foi a primeira e a última novela com um casal de protagonistas negros em um país como o Brasil.

\section{PALAVRAS-CHAVE}

Telenovela; Personagem; Processo Criativo; Ficção; Brasil; Lado a Lado.

\section{Introdução}

"Somos animais que consomem volunariamene grande quantidade de relatos e poesias. Todas as populações do globo, de todas as épocas, contam suas histórias e cantam seus poemas. Somos obrigados, por exemplo, a recontar histórias para saber sempre o que fizemos, por isso constituímos essa quantidade enorme de impressões." Este pensamento é do crítico literário e filósofo búlgaro Tzevan Todorov². A partir desta concepção, podemos inferir que nós, como seres humanos, somos nutridos de histórias: livros, jornais, filmes, relatos ou músicas. São elas que nos constituem por nos ensinar e construir nosso pensamento crítico sobre a vida. No entanto, é possível perceber que, na maioria das vezes, só nos chega uma versão do mesmo fato. Em sua palestra no TED ${ }^{3}$, Chimamanda

\footnotetext{
1 Artigo derivado de monografia de graduação em Jornalismo, orientada pela professora Tatiana Siciliano e apresentada em dezembro de 2019.

2 GARCIA, Bruno. Entrevista: Tzvetan Todorov Só a ficç̧ão nos salva. Academia.edu. Janeiro 2013. Disponível em: https://www.academia.edu/8584274/Entrevista com Tzvetan Todorov Acessado em: 02/02/2020

3 TEDGlobal 2009. Chimamanda Ngozi Adichie: O perigo da história única. Publicada no site TED em 2009. Disponível 
relata que, somente quando teve contato com o diferente, ela percebeu que o que sabia do mundo não era falso ou ruim, mas era limitado a uma única história. Ela afirma que, assim como o mundo político e econômico, as histórias são definidas por como são contadas, por quem as conta, quando as conta e quantas vezes são contadas. A fim de enriquecer a visão do mundo de quem lê, esse trabalho irá analisar a versão do Rio de Janeiro no início do século XX apresentada pela novela Lado a Lado.

A telenovela Lado a Lado estreou na TV Globo no dia 10 de setembro de 2012 e foi exibida até 8 de março de 2013. Com 154 episódios escritos por Claudia Lage e João Ximenes Braga e direção-geral de Dennis Carvalho e Vinícius Coimbra, trama se baseia na forte amizade de Isabel (Camila Pitanga) e Laura (Marjorie Estiano). As protagonistas pertencem à classes sociais distintas e buscam viver suas vidas de forma independente, reivindicando direitos iguais aos dos homens, em um contexto social do Rio de Janeiro no início do século XX. As temáticas centrais tratadas na novela são, portanto, a luta das mulheres para ter poder de escolha dos seus papéis sociais e também a luta dos negros para a construção de uma identidade negra após a recém abolição da escravidão ${ }^{4}$, tendo como pano de fundo momentos históricos reais, a exemplo das revoltas da $V^{2}$ cina $^{5}$ e Chibata ${ }^{6}$. Ela nos dá uma versão diferente da convencional sobre a época, dando luz a camadas sociais consideradas marginalizadas, como os negros e as mulheres, ao ter o primeiro casal de protagonistas negros na televisão e fazer da trama principal a amizade entre duas mulheres.

Ao refletir sobre a representatividade de grupos marginalizados historicamente na sociedade, não deve-se ignorar como se desenvolve esse processo dentro das telenovelas. Portanto, o objetivo deste trabalho é compreender como o brasileiro é abordado na telenovela Lado a Lado, qual o processo criativo de construção da obra e a importância desta, que foi a primeira e última telenovela com um casal de protagonistas negros na maior emissora de televisão do país.

https://www.ted.com/talks/chimamanda ngozi adichie the danger of a single story/transcript?language $=\mathrm{pt}$ \#t-12670 Acessado em: 02/02/2020.

\footnotetext{
${ }^{4}$ Abolida no dia 13 de maio de 1888, a escravidão teve uma longa permanência no Brasil, que foi o último país das Américas a abolí-la. Cf. Entrevista com historiador Luiz Felipe de Alencastro publicada pela BBC. Disponível para acesso em https://www.bbc.com/portuquese/brasil-44091474. Acessado em 20/11/2019.

5 A Revolta da Vacina foi um motim popular em 1904 no Rio de Janeiro, contra a vacina obrigatória contra varíola. Para maiores informações, ver Nicolau Sevcenko, 1984.

${ }^{6}$ A Revolta da Chibata foi uma revolta de marinheiros negros da Marinha Brasileira contra os castigos físicos, os maus tratos e os baixos salários exclusivamente dos marinheiros negros Cf. Vídeo explicativo do jornalista Eduardo Bueno. Disponível para acesso no canal oficial do jornalista no YouTube https://www.youtube.com/watch? $v=5 \mathrm{~Sv} 6 \mathrm{HrN}-\mathrm{Rt4}$ e também no canal oficial da TV Senado no YouTube https://www.youtube.com/watch?v=rtfeSOWSXhY. Acessados em 20/11/2019.
} 
Mesmo com as evoluções tecnológicas e as mudanças de hábito de consumo audiovisual no Brasil ${ }^{7}$, analisar questões ligadas a televisão ainda é cabível porque a TV aberta segue sendo o veículo que recebe o maior aporte publicitário ${ }^{8}$ e a TV Globo continua liderando ${ }^{9}$ a audiência. É uma questão cultural; não só porque uma boa parte da sociedade não tem acesso a essas novas formas de TV, mas também por ser um hábito muito forte na vida dos brasileiros, que hoje une o mundo das redes sociais com a telenovela. Diante deste quadro, podemos inferir que ela continua sendo um importante veículo de comunicação, influenciando comportamentos, pautando outros programas e fazendo parte do dia a dia da comunidade.

Apesar de ser, antes de mais nada, uma narrativa ficcional, a teledramaturgia (principalmente quando é de época) contém uma rica pesquisa de fatos históricos e seu enredo conta esses fatos. Logo, os telespectadores reconhecem na verossimilhança muito bem embasada a ilustração de momentos marcantes da história, fazendo da telenovela um importante meio de construção do imaginário de um passado. Essa verossimilhança se dá não somente pela narrativa, mas também por toda caracterização presente nas cenas: figurino, cenário, músicas, coloração, forma de falar e agir dos personagens, etc. Por serem uma representação social, são criadas a partir de códigos compartilhados, bem como disseminam outros. É uma via de mão-dupla: a TV constrói o povo e é construída por ele (IMMACOLATA, 2009). Por isso, também acabam por reforçar certos estereótipos sobre o tipo nacional, como a trabalhadora sofredora, o malandro, o desonesto, o honesto demais, etc (BACCEGA, 1998).

Tendo em vista o debate sobre telenovela e construção de imaginário, acredito ser imprescindível abordar brevemente a história desse meio de comunicação. A TV chegou no Brasil nos anos 1950, ainda com muita influência da linguagem do rádio e do teatro (BORELLI, 2001). Somente no final dos anos de 1960, início de 1970, as evoluções tecnológicas possibilitaram mudanças cruciais: a criação do videotape permitiu maior planejamento nas produções; as câmeras mais leves, que podiam ser carregadas nos ombros, permitiram a saída das gravações do estúdio para a rua; e a chegada das cores

\footnotetext{
7 Brasil tem menos casas com TV paga; vídeo na internet cresce. Meio e Mensagem, DEZ 2018. https://www.meioemensagem.com.br/home/ultimas-noticias/2018/12/20/consumo-de-video-via-internetcresce-em-relacao-a-assinantes-tv-a-cabo.html Acessado em 20/11/2019.

8 Cf. dados do Conselho Executivo de Normas Padrão (Cenp), a televisão aberta recebeu 58,3\% dos recursos publicitários em 2018, seguida muito de longe pela internet (17,7\%). Disponível em: https://www.meioemensagem.com.br/home/midia/2019/04/10/mercado-publicitario-movimenta-r-165bilhoes-em-2018.html Acessado em: 20/11/2019.

${ }^{9}$ Cf. Dados do relatório do Katar Ibope Media. Disponível em: https://www.kantaribopemedia.com/audienciado-horario-nobre-15-mercados-15-04-a-21-04-2019-2-2-2-2-2-2-2-2-2/ Acesso em 20/11/2019.
} 
na televisão modificou os conceitos de cenário, figurino e iluminação (ALENCAR, 2002). A partir deste ponto, há uma mudança do foco temático dos roteiros, que passam retratar a realidade brasileira, com incorporação de debate crítico e questões sociais e culturais dos personagens. São as chamadas "novelas verdade" (BORELLI, 2001). Podemos citar como exemplos a telenovela Irmãos Coragem (Janete Clair, 1970-71) e Gabriela (Walter George Durst, adaptação de Jorge Amado, 1975).

A novela Lado a Lado é também um exemplo de "novelas verdade" que, além de retratar a realidade, agrega à credibilidade a verossimilhança dos fatos históricos que mostra. Ela passou no horário das $18 \mathrm{~h}$ que foi, a partir de 1975, é reservado às adaptações da literatura brasileira para a TV. A boa qualidade dessas adaptações deu prestígio às narrativas das telenovelas, principalmente à Rede Globo (ALENCAR, 2001). A credibilidade e aderência conquistadas pela Rede Globo gerou uma integração nacional que, no livro Um país no ar, foi citado como "menos entre cidadãos e mais entre consumidores de bens culturais simbólicos". Conforme Maria Rita Kehl:

\begin{abstract}
"A integração se dá no nível do imaginário. Ligados, em cadeia nacional, na fala da Rede Globo, estamos de alguma forma pertencendo a um todo unitário que nos contém e nos significa como brasileiros de um outro Brasil...Trata-se agora do Brasil moderno, urbano, industrializado. $E$, nós, o público global, brasileiros de um outro Brasil, nos vemos refletidos todos os dias nas imagens de uma sociedade de consumo. Como público e como mercado consumidor: assim se dá a integração entre os brasileiros, via Embratel". (KEHL apud ALENCAR, 2001, p.54)
\end{abstract}

\title{
2. Fictio e o processo criativo de Lado a Lado
}

O tom de realidade presente nas telenovelas as transformam em um assunto comentado por todos, se tornando até o centro dos debates no dia a dia da sociedade. Conforme as pessoas vão se identificando com as tramas, o interesse pelas mesmas aumenta e o ficcional vai se misturando cada vez mais ao real. Por isso, acredito ser necessário um aprofundamento sobre o processo de criação da novela, passando pelo roteiro e fazendo um paralelo com entrevistas dos autores de Lado a Lado, Claudia Lage e João Ximenes Braga.

Embora o público saiba que se trata de uma obra ficcional, ele entra na trama através da emoção gerada pela obra. A empatia do público com os sentimentos dos personagens, como amizade, amor e justiça, são os conectores da emoção do sentir com a razão de saber que o que está sendo exibido é ficcional (MAZZIOTTI, 2006). Essa identificação é 
produto de uma característica fundamental das narrativas melodramáticas: a luta diária dos personagens (que reflete a luta diária das pessoas) em busca de ter um final feliz. Esse é um dos objetivos primordiais da vida humana.

Pensando nesse gênero narrativo e no seu efeito no público, considerei a elaboração sobre ficção que Luiz Costa Lima fez em uma palestra publicada na Revista Eutomia. Ele afirma que na tradução da palavra do grego (fictio) para o latim (fingere), houve uma divisão de dois sentidos: tanto de invenção e criação, quanto de mentira e fraude. Para explicar as nuances da palavra, o autor começa defendendo a ideia de que "Antes de a ficção dizer a respeito à literatura, a ficção diz respeito ao nosso cotidiano" (LIMA, 2008, p.172) e que nessa "ficção não-literária" existem alguns tipos de compreensão da ficção. A chamada "ficção conjectural" é o tipo que não se justifica naturalmente, mas sim, é uma conjuntura da realidade. Já a "ficção necessária", é uma ideia sólida de verdade, mesmo que não seja comprovada, é como um conceito base para a formulação de outras interpretações, como por exemplo, o conceito de liberdade e poder.

Costa Lima também afirma que a ficção literária é declaradamente uma ficção e não uma versão do real. Assim, a verdade da ficção é ela por si só. Logo, a ficção mostra com as suas não-verdades tudo que nós acreditávamos que fosse verdade e, dessa forma, apresenta o que é verdadeiro (LIMA, 2008, p.176). Nesse sentido, Lado a Lado confronta a ideia de igualdade étnica e de gênero - uma "ficção necessária" para muitos na sociedade brasileira - ao colocar que essa igualdade não existia em 1911 e, através das não-verdades cotidianas, mostra que ainda não existia em 2013.

Além da questão já intrínseca em uma obra de fiç̧ão, Lado a Lado é tida como referência do passado por questões de verossimilhança já apresentadas neste trabalho. Ela se torna, com isso, o imaginário do passado. Trabalhando esse pensamento dentro do processo de criação, podemos fazer um paralelo dessa verossimilhança com a crescente onda tecnológica. Em "Encenação da realidade: fim ou apogeu da ficção?", Vera Lúcia Figueiredo nos trás a ideia de que com a sensação de encolhimento do planeta - devido a grande troca cultural possibilitada pela evolução tecnológica - e também com o movimento do mercado audiovisual de produzir remakes e reciclagens, o passado é trazido de volta ao presente (FIGUEIREDO, 2009). Figueiredo coloca isso como uma mudança na forma de vivenciar o tempo, o espaço e o passado das coisas. Essa alteração na forma de ver, segundo ela, gerou uma valorização das "pequenas narrativas", que privilegiam pessoas comuns que, por sua vez, trazem as versões (e identidade) das comunidades marginalizadas. 
As pequenas narrativas, voltadas para o passado, se expandem não só na historiografia, mas em diversos campos, sendo vistas como instrumento de autodefesa diante da experiência cotidiana de fragmentação e dispersão e como estratégia de resistência através da qual grupos colocados à margem pela grande História afirmam sua memória e identidade. (FIGUEIREDO, 2009, p.134).

Existem dois pontos cruciais em Lado a Lado que deixam claro a mensagem da novela de verossimilhança entre o real e o ficcional, a fim de conectar o passado do presente: a trilha sonora e a última cena do último capítulo. No primeiro episódio de Lado a Lado, a primeira cena é acompanhada pela música "Samba de Primeira" de Marcelo D2, que mistura samba e rap. Todas as demais músicas da novela são contemporâneas. Isso já faz uma conexão entre o que está sendo mostrado na cena e dito na música com o presente do telespectador. Já no último capítulo, essa ligação é de uma forma mais direta. A penúltima cena é a festa de casamento de Isabel e Zé Maria no morro, filmada de cima, fazendo um movimento de zoom out, se afastando dos personagens. Logo em seguida, na última cena da novela, aparece o Morro da Providência de 2013, cercado de prédios e até com uma coloração de imagem em um tom menos amarelo (como era a coloração da novela) e mais branco (dando um tom de autalizade).

Para reforçar essa verossimilhança, as telenovelas recorrem a tipificações de fácil compreensão para conseguir se comunicar com o público heterogêneo que se pretende falar. Os personagens são compostos dessas tipificações e estereótipos, sendo eles, portanto, "os tipos aceitos, os padrões correntes" (BACCEGA, 1998, p.8). Ao tratar do processo criativo de construção da novela, é necessário destacar como é a criação dessas personagens. Especialmente porque em Lado a Lado, elas fomentam a referência do passado tanto quanto os fatos históricos apresentados. Para compreender o desenvolvimento desses personagens históricos na teledramaturgia brasileira, entrevistei João Ximenes Braga em sua casa, em maio de 2019.

João Braga afirmou que uma das preocupações que ele e Claudia tiveram com relação aos personagens foi não fazer uma novela sobre a vida de uma figura que realmente existiu, como (exemplo do próprio Braga) A Lista de Schindler. Contudo, devido às pesquisas, trabalhos anteriores de ambos e também a vontade de fazer a novela o mais verossímil possível, eles se inspiraram em pessoas reais e ficcionais para compor suas personagens. 
Segundo Braga, o personagem Zé Maria foi inspirado em quem ele chamou de "o grande herói do século XX": João Cândido ${ }^{10}$. Ele explicou que eles não queriam retratar a vida do marinheiro, por conta de sua própria trajetória, marcada pela luta pelos direitos dos negros. Esta era a inspiração para o personagem com as características do Zé Maria:

Não queríamos fazer uma novela sobre um personagem real, então a gente colocou este personagem que estaria ali naquele... ele nem estava no mesmo barco que o João Cândido, pra gente não ter que fazer o João Cândido. Porque realmente, a Revolta da Chibata aconteceu em três fragatas simultâneamente, que se comunicavam por rádio. O Zé Maria não estava na mesma que o João Cândido, ele estava na outra. [...] não era só uma vontade de homenagear o João Cândido, é porque assim, toda a história do João Cândido é: cara, sabe a jornada do herói? É aquilo ali tatuadinho. Assim, tudo que você tem na jornada do herói, você tem na do João Cândido. Está lá: check, check, check. Então assim, a inspiração do Zé Maria foi o João Cândido. Pelo menos assim, ele não era o João Cândido, como a gente já conversou, ele era um integrante ali da revolta, mas a inspiração era o João Cândido. ${ }^{11}$

Com relação as personagens femininas, João Braga confirmou que Laura foi inspirada em Júlia Lopes de Almeida ${ }^{12}$ e em outras mulheres da época que também escreviam e na questão de que muitas tinham que assinar seus textos com pseudônimos masculinos. No caso de Laura, ela assinava com o nome de "Paulo Lima" e na reta final da novela, ela batalha em diversos jornais para tentar publicar uma reportagem sobre um assunto polêmico assinadas por ela. No último capítulo, o marido de Laura é cotado para ganhar o prêmio de jornalista revelação do ano, mas ele descobre que o prêmio era de Paulo Lima e que não deram o prêmio para ele porque descobriram que era Laura, uma mulher, quem escrevia. Ele então arma um plano para que ela fique com o prêmio que ganhou com seus próprios esforços de reportagem. Vale lembrar que Júlia Lopes de Almeida assinava suas reportagens e romances, e que foi uma das idealizadoras da Academia Brasileira de Letras, mas por ser uma mulher, seu marido Filinto de Almeida ${ }^{13}$ é quem recebe uma cadeira na Academia. Essa história real de Julia é contada em um dos capítulos de Lado a Lado.

João Braga afirma também que a personagem Isabel (Camila Pitanga) foi um mix de inspirações e que em uma de suas fases, ela foi inspirada em Clara dos Anjos ${ }^{14}$, de

\footnotetext{
10 Para saber mais, ver "João Cândido 1910 - 1968: arqueologia de um depoimento sobre a Revolta dos Marinheiros, de José Miguel Arias Neto. Disponível em: http://www.uel.br/cch/cdph/arqtxt/JoaoCandido19101968.pdf

${ }_{11}$ A entrevista com João Ximenes Braga foi realizada por mim, em maio de 2019, está transcrita na íntegra e segue no ANEXO desta monografia.

12 FENSKE, Elfi Kürten. Júlia Lopes de ALmeida - A escritora da Belle Époque Tropical. Templo Cultural Delfos, maio/2014. Disponível no link: http://www.elfikurten.com.br/2014/05/julia-lopes-de-almeida.html Acessado em: 20/11/2019.

13 Para saber mais, ver a breve biografia dele no site da Academia Brasileira de Letras. Disponível em: http://www.academia.org.br/academicos/filinto-de-almeida

14 Para saber mais, ver A Leitura Urbana de Lima Barreto em Clara dos Anjos, de Adriana Carvalho Silva. Disponível em: https://www.e-publicacoes.uerj.br/index.php/espacoecultura/article/viewFile/3559/2479
} 
Lima Barreto. Em uma entrevista ${ }^{15}$ concedida em 01/04/2013 ao blog Blogueiras Feministas, Claudia Lage explica qual foi o pensamento que originou as principais características das personagens Isabel e Laura:

\begin{abstract}
Laura e Isabel viveram conflitos bem contemporâneos, apesar da novela se passar em 1910. A premissa da autoestima de Laura e Isabel é conciliar amor com trabalho, amor com independência, sem abrir mão das conquistas pessoais. É isso que sempre esteve em primeiro plano na novela, e não ser resgatada pelo príncipe encantado ou amarrar seu homem a qualquer preço. Gosto de pensar sim que as mocinhas estão mudando, mas vejo a representação feminina ainda muito presa nas idéias românticas, no sentido conservador, que não correspondem muito às mulheres de hoje. O conflito entre amor e trabalho na vida contemporânea é um tema, surpreendentemente ao meu ver, pouco explorado. Há tanto para se debater sobre o assunto, porque os papéis sociais que eram muito fortes na época da novela, hoje sofreram um deslocamento enorme, mas ainda não estão totalmente resolvidos nem redefinidos. E parece evidente que precisa de uma redefinição, mas há uma resistência enorme na sociedade como um todo em assumir plenamente as mudanças feitas e em lidar com as suas consequências.
\end{abstract}

Ao analisar as personagens de Isabel e Laura (principalmente considerando que a penúltima cena da novela é exatamente as duas protagonistas conversando sobre sua amizade e sobre suas conquistas e desafios), é possível concluir que elas são as figuras centrais de toda a trama porque é com as suas experiências que são transmitidas os principais temas da novela: racismo, machismo, desigualdade e corrupção. Claudia Lage afirma $^{16}$ que a ideia da novela foi, desde o início, abordar a questão social e da emancipação feminina e que viu nas personagens a melhor forma de abordar essas questões:

Desde o início pensamos em falar sobre a questão racial e a emancipação feminina. O início do século XX é uma época perfeita para isso, já que é o início, a semente ainda, da modernidade mas ainda traz a mentalidade conservadora do século XIX. O embate entre essas duas mentalidades, na novela, se deu muito pelos conflitos entre a Laura e a sua mãe, a Constância. Laura tinha a consciência de que a mulher tinha o direito de se emancipar, Constância insistia em manter os valores patriarcais, onde o destino feminino se limitava à vida doméstica e familiar. A novela é feminista porque além de falar da emancipação feminina traz personagens femininos com uma postura ativa, consciente de seus direitos, agentes do próprio destino, diferente das mocinhas convencionais do folhetim.

\footnotetext{
15 Bia. Entrevista: Claudia Lage, autora da novela Lado a Lado. Publicada no site Geledés em 01/04/2013. Disponível em: https://www.geledes.org.br/entrevista-claudia-lage-autora-da-novela-lado-a-lado/ Acessado em: 20/11/2019.

16 Bia. Entrevista: Claudia Lage, autora da novela Lado a Lado. Publicada no site Geledés em 20/11/2013. Disponível em: https://www.geledes.org.br/entrevista-claudia-lage-autora-da-novela-lado-a-lado/ Acessado em: 20/11/2019.
} 
Além do feminismo, a novela possui dois personagens protagonistas negros, o que até então era inédito na TV brasileira. Sobre isso, Claudia Lage afirma que houve uma proposta de colocar os negros que não "abaixavam a cabeça" e que não tinham uma postura conformista. João Ximenes Braga revelou que, para Zé Maria, a inspiração poderia ter sido os grandes escritores negros que existiram (como Luiz Gama e Lima Barreto), mas que eles optaram propositalmente pelo viés da luta presente na história de João Cândido porque queriam um personagem forte nesse sentido. Ele explicou também o porquê da escolha de manter as personagens negras da trama sem grande poder financeiro (com a exceção de Isabel e, posteriormente, Zé Maria):

A gente já está falando assim do público resistente. A gente sabia que a gente tinha que mostrar a ascensão dessas pessoas. A gente sabia que, se no primeiro capítulo a gente entrasse com uma família negra ali situada, rica e não sei o que, as pessoas não iam comprar. Então a gente começou com dois protagonistas negros, começando por baixo, e a gente mostrou a ascensão deles. Isso é importante. A gente mostrou a ascensão deles. Até porque ali era justamente a primeira geração...(de negros pós Lei do Ventre Livre ${ }^{17}$ ) Porque assim, tinha barão do café negro ainda durante a escravidão. Sempre houve negros que, de uma forma ou de outra - negros alforriados mesmo durante a escravidão - que conseguiam galgar patamares, mas ali para aquela história, para o público de novela das 18h, naquele momento para uma coisa tão inédita, era importante mostrar a ascensão, não já começar com eles coisa.

Outro ponto com relação ao racismo tratado na trama é a influência do cineasta e pesquisador Joel Zito Araújo ${ }^{18}$. João Braga o considera como um dos responsáveis pelo número de atores negros presentes e pela forma de abordar o assunto. Ele contou que leu - livro de Joel Zito $A$ Negação do Brasil na época que trabalhava no jornal e que imediatamente quis fazer uma reportagem sobre o assunto porque, o assunto o marcou. "Se dali há 15 anos eu fui escrever novela e tive essa gana de botar atores negros para protagonizar, foi muito por causa do tapa na cara que o Joel Zito me deu uma década antes". O próprio Joel Zito afirmou, na época, que Lado a Lado era um marco na representação do negro nas telenovelas ${ }^{19}$.

\footnotetext{
17 Lei assinada em 28/09/1871, declarava que a partir daquela data, os filhos de escravas nascidos no Brasil eram livres. Para saber mais, ver " A Lei do Ventre Livre". Disponível em: https://www.geledes.org.br/lei-ventrelivre/ Acessado em 20/11/2019.

${ }_{18}$ Centro Afro Carioca de Cinema. Disponível em: http://afrocariocadecinema.org.br/joel-zito-araujo/ Acessado em 20/11/2019.

19 FARIAS, Patrícia. Joel Zito Araújo: um cineasta e sua missão. Z Cultural: Revista do Programa Avançado de Cultura Contemporânea. Duas Entrevistas: Milton Santos e Joel Zito Araújo. Publicação 02. Ano III. Disponível em: http://revistazcultural.pacc.ufrj.br/duas-entrevistas-joel-zito-araujo-e-milton-santos/ Acessado em 20/11/2019.
} 
No entanto, apesar da novela ser, reconhecidamente, uma mudança na forma de representação do negro e ao contrário do que disse Joel Zito, Lado a Lado foi um "ponto fora da curva", mas não chegou a ser uma mudança radical nas telenovelas. Depois de Lado a Lado, não tivemos mais nenhuma outra com um casal de protagonistas negros.

Por que Lado a Lado foi a primeira novela com protagonistas negros e a última na TV Globo? Esse questionamento me veio quando entrevistei João Braga. Desde aquele dia, eu fiz uma pesquisa sobre as novelas exibidas às $18 \mathrm{~h}$, às $19 \mathrm{~h}$ e às $21 \mathrm{~h}$ e, de fato, não encontrei um casal de protagonistas negros em nenhuma.

A falta de protagonistas negros não é por acaso, mas sim, fruto de um processo estrutural de racismo que marca a cultura do Brasil. Em seu artigo "O Negro na Dramaturgia, um caso exemplar da decadência do mito da democracia racial brasileira", Joel Zito desconstrói o erro de se confundir mestiçagem com igualdade racial já no primeiro parágrafo:

Examinar a representação dos atores e atrizes negras em quase 50 anos de história da telenovela brasileira, principal indústria audiovisual e dramatúrgica do país, é trazer à tona a decadência do mito da democracia racial, sujando assim uma bela, mas falsa imagem que o Brasil sempre buscou difundir de si mesmo, fazendo crer que a partir de nossa condição de nação mestiça superamos o "problema racial" e somos um modelo de integração para o mundo. (ARAÚJO, 2008, p.979).

Dos anos 1960 para cá, a representação do negro vem sendo modificada lentamente. No início, a mulher negra tinha os papéis de escrava, empregada doméstica ou da "mulata destruidora de lares". Mesmo com essa "variedade", as personagens de empregadas domésticas predominavam. Elas se encaixam no estereótipo das mamies, comum no cinema e na televisão estadunidense. Um exemplo foi a mamãe Dolores, interpretada por Isaura Bruno na popular novela O Direito de Amar, que foi muito popular na época (anos 1990). Mesmo com os negros sendo interpretados em situações subalternas e com as relações paternalistas entre patrões brancos e empregadas negras, "as telenovelas desse período procuravam confirmar o mito da democracia racial brasileira e da convivência pacífica entre as raças" (ARAÚJO, 2008, p.980).

Na década de 1970, o Brasil passou por um período econômico próspero e, por conta disso, as telenovelas tratavam como tema principal as questões dos brasileiros na busca por ascensão social. Apesar de ser uma busca do país como um todo, poucos autores, como Janete Clair por exemplo, trataram dos negros construindo esse crescimento profissional, vide o psiquiatra Dr. Percival, interpretado por Milton Nascimento em Pecado Capital 
(ARAÚJO, 2008). Em 1976 estreou a novela que marcou a história do audiovisual brasileiro por consolidar a posição do Brasil como um grande exportador de telenovelas: Escrava Isaura (ALENCAR, 2002). Esta foi a primeira personagem protagonista negra no papeltítulo da novela, mas interpretada por uma atriz branca (Lucélia Santos). As personagens negras não possuíam um destaque como protagonistas ou antagonistas. O papel-título de uma novela só viria a ser interpretado por uma mulher negra nos anos 1990, com Taís Araújo em Xica da Silva na TV Manchete. "Taís Araújo em 2004, após 7 anos de trabalho na Rede Globo, na novela Da Cor do Pecado, iria ocupar o posto de primeira protagonista negra em 40 anos de história da emissora, que é líder de audiência desde a segunda metade dos anos 70". (ARAújo, 2008, p.980).

Ao observar todos esses fatos, é possível concluir que os atores e atrizes negros não são colocados nos papéis de relevância e nem têm o mesmo destaque que os profissionais brancos. Se evidencia que as características de pessoas brancas permanecem como o padrão ideal de beleza e seguem reforçando a superioridade branca. Um forma de perceber isso é observar os padrões físicos dos personagens protagonistas "galãs": traços nórdicos que caracterizam a beleza europeia. Os profissionais negros não são escolhidos para representar o estereótipo da beleza e também não são o foco de empatia do público com a novela. Eles são distribuídos de acordo com suas características físicas, "seu formato de rosto, suas nuanças cromáticas de pele e textura do cabelo, portanto de acordo com seu grau de mestiçagem". (ARAÚJO, 2008, p.983).

Em seu artigo, Joel Zito (2008) deixa claro que as telenovelas não representam o povo brasileiro e suas características étnico-raciais. Segundo ele, a falta de a relevância dos papéis interpretados por atores e atrizes negros soma-se ao fato de que, até o final dos anos 1990, não tinha nenhum personagem negro em um terço das novelas da Rede Globo. Tendo em vista que $50 \%$ da população do Brasil é afrodescendente, é possível afirmar que as representações, de fato, não representam. Em um país de maioria negra e pobre, ter novelas com protagonistas brancos que são filmadas na zona sul do Rio de Janeiro é contraditório.

A falta de visibilidade do povo negro do país presente nas telenovelas não se faz tão evidente porque em suas construções narrativas, o racismo é abordado como algo negativo. Mas é somente uma característica ruim do vilão e não como um traço fortemente estruturado na sociedade brasileira. Isso acaba negando a existência do preconceito, compactuando com o "mito de democracia" racial e dando continuidade ao lugar 
subalterno em que o negro é colocado, sem dar a devida importância do negro na história e na cultura do país.

A telenovela [...] pactua com um imaginário de servidão e de inferioridade do negro na sociedade brasileira, participando assim de um massacre contra tudo aquilo que deveria ser visto como nosso maior patrimônio cultural diante de um mundo dividido por sectarismos e guerras étnicas e religiosas, o orgulho de nossa multirracialidade. (ARAÚjO, 2008, p.982).

Após a contextualização do como o negro é tradicionalmente representado nas telenovelas, deve-se destacar que na novela Lado a Lado os atores negros têm um lugar de protagonistas. A atriz Camila Pitanga (Isabel) e o ator Lázaro Ramos (Zé Maria) ocupavam dois dos quatro papéis principais da trama. Além dos dois, as demais personagens negras também constituem a narrativa central da novela. A telenovela mostra as mudanças do Rio de Janeiro e insere o negro no mesmo espaço urbano, mostrando como ele faz tão parte da história quanto os brancos (BACCEGA, MELLO e BARRETO, 2014).

Lado a Lado reconstrói o fato histórico através do olhar do povo que conta a história vivida, seus protagonistas que fazem parte das classes menos favorecidas da sociedade de ontem e de hoje, trazendo para a atualidade essas discussões. (BACCEGA, MELLO e BARRETO, 2014, p.7)

No entanto, como já foi dito, contrariando todas as expectativas, Lado a Lado não foi o primeiro passo de uma mudança, mas um ponto fora da curva; curva esta que voltou ao seu eixo logo após o fim da novela. A falta de protagonistas negros se tornou pauta novamente só em momentos pontuais do pós-Lado a Lado, como em 2016, quando tevese a primeira protagonista negra de $\mathrm{Malhação}^{20}$, a atriz Aline Dias. No entanto, além de não ser um casal de atores negros como protagonistas, também não fez do racismo e da luta por direitos iguais os fios condutores da trama. Em 2018 o assunto voltou às discussões quando a TV Globo lançou a novela O Segundo Sol, que passava na cidade de Salvador (localizada na Bahia, que é o estado brasileiro com mais negros ${ }^{21}$ ), e nenhum dos protagonistas era negro. Apesar de ter chamado a atenção de alguns, a falta da maioria do elenco negro não mudou. O movimento parou em Lado a Lado e não foi mais retomado. Nas palavras de João Braga:

Quando a gente fez Lado a Lado, a gente achou que Lado a Lado seria a primeira porque assim, Lado a Lado era - já tinha tido Thais

\footnotetext{
20 BELLO, Camilla. Primeira protagonista negra de Malhação, Aline Dias fala sobre carreira e preconceito. Publicada dia 05/12/2016. Disponível em:https://voque.globo.com/beleza/gente/noticia/2016/12/primeiraprotagonista-negra-de-malhacao-aline-dias-fala-sobre-carreira-e-preconceito.html Acessado em: 20/11/2019. 21 Uma a cada 5 pessoas na Bahia se declara preta, segundo IBGE. Publicado dia 22/05/2019. Disponível em: https://g1.globo.com/ba/bahia/noticia/2019/05/22/uma-em-cada-5-pessoas-na-bahia-se-declara-pretaaponta-ibge.ghtml Acessado em 20/11/2019.
} 
em Manoel Carlos - mas Lado a Lado os dois primeiros nomes eram de um ator [...] primeira vez que o nome de um ator negro e uma atriz negra abriam uma novela. $30 \%$ do elenco era negro e depois, a outra novela que eu fiz, Babilônia, era $40 \%$, eu contei. Assim, isso era um projeto. Que foi interrompido quando mudou de novo a direção da emissora e Cláudia e eu fomos demitidos. Isso era um projeto declarado e isso foi interrompido. E assim, o bizarro que me deixa até hoje [...] é que Lado a Lado era pra ter sido a primeira. E cinco anos depois - está para fazer seis - ela segue sendo a única. Ela teria sido um marco se ela tivesse mudado. Mas não deixaram isso acontecer e estava-se a caminho de. $\mathrm{E}$ foi interrompido. Foi um projeto interrompido. Então como eu vejo a representatividade (do negro na televisão): eu não vejo. Não tem.

\section{Considerações finais}

A linha entre o real e o ficcional, que fica cada vez mais fina, foi o grande fio condutor da colocação dos argumentos e referências neste trabalho. Um dos principais elementos narrativos que fazem da novela esse grande canal de empatia e reconhecimento social é a personagem. A criação de personagens e a estrutura de comunicação da telenovela impacta o público e coopera com a construção dela como um imaginário de passado.

Destaca-se que Lado a Lado tem fundamento, no sentido de que foi uma novela bem escrita, bem produzida, bem executada e que tratou sim, de temas importantes e marcantes da sociedade brasileira. Como foi apresentado, a novela faz um diálogo consistente entre o passado e o presente. No entanto, o fato da novela ter sido a primeira e a última com um casal de protagonistas negros deixou claro para mim que o racismo da sociedade, refletido na televisão brasileira, está longe de acabar. Especificamente na TV, este racismo está tão naturalizado que apenas poucas partes da sociedade o percebem e o problematizam; não há uma reivindicação da população como um todo para que isso mude. As novelas, os telejornais, a publicidade e tudo que é transmitido em um dos veículos de comunicação mais poderosos de um país como o Brasil, não representam os negros de uma forma coerente com a realidade e, assim, também não refletem a própria sociedade e as questões inerentes na vida de todos os brasileiros.

\section{Referências bibliográficas}

ALENCAR, Mauro. A Hollywood brasileira: panorama da telenovela no Brasil. Rio de Janeiro, Senac Rio, 2002. 
ARAÚJO, Joel Zito. O negro na dramaturgia, um caso exemplar da decadência do mito da democracia racial brasileira. Revista Estudos Feministas. 2008.

ARAÚJO, Joel Zito. A força de um desejo - a persistência da branquitude como padrão estético audiovisual. Revista USP. São Paulo, 2006.

BACCEGA, Maria Aparecida. O estereótipo e as diversidades. Comunicação e Educação, São Paulo set \dez 1998.

BACCEGA, MARIA APARECIDA ; Mello, F.C ; BARRETO, R. G. . História, ficção e realidade: a novela Lado a Lado e seu olhar sobre questões históricas brasileiras. In:

Ricardo Zagallo Camargo. (Org.). Brasil: Múltiplas Identidades - volume 2.. 1ed.São Paulo: Alameda Casa Editorial, 2016, v. 1, p. 1-1.

BORELLI, Silvia. Telenovelas Brasileiras: balanços e perspectivas. São Paulo em Perspectiva. São Paulo, 2001.

BRAIT, Beth. A Personagem. São Paulo: Ática, 1985.

HAMBURGER, Esther. Telenovelas e a interpretação do Brasil. Lua Nova. São Paulo, 2011.

IMMACOLATA, Maria. Telenovela como recurso comunicativo. Revista MATRIZes. Ano 3 - No 1 ago./dez. 2009.

MAZZIOTTI, Nora. Telenovela, industria y prácticas sociales. Bogotá: Grupo

Editorial Norma, 2006.

SICILIANO, Tatiana. O Rio de Janeiro de Artur Azevedo: cenas de um teatro urbano. Rio de Janeiro: Mauad Editora, 2014.

SICILIANO, Tatiana. Um passeio pelo Rio de Janeiro no início do século XX pela novela Lado a Lado. Rio Circular: A cidade em Pauta, Rio de Janeiro, Editora Autografia, 2016.

\section{Sites}

BELLO, Camilla. Primeira protagonista negra de Malhação, Aline Dias fala sobre carreira e preconceito. Vogue. Publicada dia 05/12/2016. Disponível em:https://vogue.globo.com/beleza/gente/noticia/2016/12/primeira-protagonistanegra-de-malhacao-aline-dias-fala-sobre-carreira-e-preconceito.html Acessado em: 02/07/2019.

Bia. Entrevista: Claudia Lage, autora da novela Lado a Lado. Geledés. Publicada em 01/04/2013. Disponível em: https://www.geledes.org.br/entrevista-claudia-lage-autorada-novela-lado-a-lado/ Acessado em: 01/07/2019.

FARIAS, Patrícia. Joel Zito Araújo: um cineasta e sua missão. Z Cultural: Revista do Programa Avançado de Cultura Contemporânea. Duas Entrevistas: Milton Santos e Joel Zito Araújo. Publicação 02. Ano III. Disponível em: 
http://revistazcultural.pacc.ufrj.br/duas-entrevistas-joel-zito-araujo-e-milton-santos/. Acessado em 02/02/2020.

'Lado a Lado' e Fernanda Montenegro vencem prêmio Emmy internacional. G1.

Disponível em: http://g1.globo.com/pop-arte/noticia/2013/11/fernanda-montenegrovence-premio-emmy-internacional.html. Acessado em 02/02/2020.

FENSKE, Elfi Kürten. Júlia Lopes de ALmeida - A escritora da Belle Époqué Tropical.

Templo Cultural Delfos, maio/2014. Disponível no link:

http://www.elfikurten.com.br/2014/05/julia-lopes-de-almeida.html Acessado em:

02/02/2020.

GARCIA, Bruno. Entrevista: Tzvetan Todorov Só a ficç̧ão nos salva. Academia.edu. Janeiro de 2013. Disponível em:

https://www.academia.edu/8584274/Entrevista com Tzvetan Todorov Acessado em: $02 / 02 / 2020$

SACCHITIELLO, Bárbara. Cenp-Meios: compra de mídia em 2018 foi praticamente igual à de 2017. Meio e Mensagem. Publicado em 11/04/2019. Disponível em:

https://www.meioemensagem.com.br/home/midia/2019/04/10/mercado-publicitariomovimenta-r-165-bilhoes-em-2018.html Acessado em: 02/07/2019.

STYCER, Maurício. Autor culpa "inimigos externos" por baixa audiência de Lado a Lado em São Paulo. UOL. São Paulo. 29/11/2012. Disponível em:

https://televisao.uol.com.br/noticias/redacao/2012/11/29/autor-culpa-inimigosexternos-por-baixa-audiencia-de-lado-a-lado-em-sao-paulo.htm Acessado em: 08/11/2019.

TEDGlobal 2009. Chimamanda Ngozi Adichie: O perigo da história única. TED. Publicada em 2009. Disponível em:

https://www.ted.com/talks/chimamanda ngozi adichie the danger of a single story/t ranscript?language $=\mathrm{pt} \# \mathrm{t}-12670$ Acessado em: 02/02/2020. 